\title{
Generational Responses to Job Security, Traditional Class Division, and the American Dream
}

\author{
Yakasah Wehyee \\ Political Science Department, Hamline University, Saint Paul Minnesota, USA \\ Email: kingyakasah@gmail.com
}

Received 8 March 2015; accepted 8 April 2015; published 9 April 2015

Copyright @ 2015 by author and Scientific Research Publishing Inc. This work is licensed under the Creative Commons Attribution International License (CC BY). http://creativecommons.org/licenses/by/4.0/

(c) (i) Open Access

\begin{abstract}
This paper examines some of the leading theories around the generation question. Using data gathered from the Survey Documentation and Analysis-Frequencies/Cross Tabulation Program, this paper analyzes generational responses to three issues: job security, traditional class division, and the American dream. The purpose of this research is to arrive at which theory of generation more accurately explains generational behavior.
\end{abstract}

\section{Keywords}

Job Security, Class Division, American Dream, Life Cycle, Collective Consciousness, Generation

\section{Introduction}

In recent history, there have been much speculation on the impact of generation upon politics. In this conversation, many authors such as Karl Manheim, Susan MacManus, and Michael Delli Carpini, have attempted to provide a clear meaning to the fundamental question of what it means to be a generation. Every author's attempt to find a clear definition of a generation has been met with another's attempt at the same end. Therefore, there exists no clear explanation or definition of what constitutes a generation, and how it is politically significant. As a result, people are more confused now than ever when it comes to understanding the concept of generation. Still, these conversations are much needed, especially now in the midst of trying to define the Millennial Generation. This paper will illustrate generally, some of the key concepts surrounding the generation question. The second objective of this paper is to provide some analysis as a means of understanding how, if at all, generation affects perceptions in three areas: job security, traditional class division, and the American dream. From these findings along with some of the leading theories in the field, this paper will juxtapose some of the leading theories with 
the data results as well as provide new insight to what the implications of the findings might mean.

\section{Literature Review}

Much of the research and debate around generational politics derives from the ideas developed by Karl Manheim. For Mannheim, a generation is not necessarily defined by age but rather, by conscious awareness. Through this perspective generation can be seen as cohorts who consciously identify with each other and the times (Mannheim, 1952). He believes that location and biology are important but that the conscious awareness of who one is in time creates the bond that is called a generation. He also believes that this consciousness can develop without cohorts knowing of each other. Mannheim argues that generations are molded to shift their specific role in society (Mannheim, 1952). Michael Delli Carpini, another leading voice in the debate of generation and generational politics adds another dimension to the conversation. Like Manheim, he also believes that there must be some collective awareness. He adds that before cohorts can become a generation, they must experience a major destabilizing event which then leads to a rethinking (Carpini, 1989). This rethinking, he contends, is the collective consciousness essential to create the bond necessary to form a generation. Where he differs from Manheim's interpretation is that he believes that how the consciousness is interpreted may differ, but the members of the generation are aware of each other's existence.

In her book Young V. Old: Generational Combat in the $21^{\text {st }}$ Century Susan MacManus associates generation more rigidly with age. Her thesis is that the ensuing conflict within $21^{\text {st }}$ century America is a result of age differences; that the schism of America is young vs. old. She argues that policy interest and civic engagement positively correlate to ones' age; that older people strongly support issues which affect their cohort such as Medicare and social security while the young tend to support issues that affect their cohorts more; such as education (MacManus, 1996). The fact that the different age cohorts view each issue differently therefore creates an ostensible rift due conspicuously to age, according to McManus. In this way McManus's focus is less about generational differences and more on age and its lifecycle as the central variable affecting political action. In their book Millennials Rising William Strauss and Neil Howe see the current socio-political atmosphere differently. They describe it as a conflict between the Millennial Generation and preceeding generations that are still alive: including, the Silent Generation, the Baby Boom Generation, and the Gen Xers (Howe \& Strauss, 2000). For example, their research has found that Millennials have been raised in an atmosphere of "confident individualism," where by parents have been obsessed with uplifting their Millennial children's self-esteems. This sort of emotional attention according to Howe and Strauss has not been characteristic of any other generation (Howe \& Strauss, 2000). Their research has also found that Millennials are coming of age in the most "socially fragmented" environment America has ever experienced. This trend is characterized by the pernicious gap in areas of "income, race, language, and lifestyle" (Howe \& Strauss, 2000). Each of these views has either directly or indirectly influenced this research. It is the goal of this paper to arrive at which theory best explains the results of findings of this paper.

\section{Method}

The data in this research is derived from the Survey Documentation Analysis-Frequencies/Cross Tabulation Program (SDA Frequencies/Cross Tabulation). Using a univariate approach, this research identifies age as an independent variable. The age variable is divided between those cohorts between ages 18 - 30, 31 - 50 and 51 95. This age division is largely influenced by popular understanding of general age breakdown along generational lines. It is noted that William Strauss and Neil Howe as well as MacManus and other leading authors roughly breakdown generational cohorts along these lines. Three variables are analyzed as dependent variables: Job satisfaction, class division, and the American dream. The decision to analyze these particular variables is influenced by the leading notion that the economy and people's perception of progress in this area is the main indicator for political participation (Walsh, Jennings, \& Stoker, 2001). There are three graphs in total; one for each of the dependent variables. The first graph which examines job security asks the respondents to rate how important job security is to them. The scale rang is from 1 - 7; one being least important and 7 being very import. The second dependent variable tested is class division. Respondents were asked to rate the degree to which traditional class divisions still exists in America. This scale ranges from 1 - 4; 1 representing those who strongly agree that traditional class division still exists and 4 representing those who strongly disagree. The final variable studied is how well one is able to live in America. This question is basically the classic American dream question and attempts to see how various cohorts view it. The graphs are displayed and discussed. 


\section{Data/Discussion}

In Table 1, when asked how important job security is, unsurprisingly, more people between the ages 18 - 30 gave higher marks (47.3\%, 28.4\%) than people between the ages 31 - 50. Only 11.3\% rated it as not important compared to $30 \%$ of those between ages $31-50$. This issue appeared to be less important still to those cohorts between ages 51 - 95. 58.7\% of this group thought job security was not important. From these results one can infer that for the young, it is more difficult to hold on to a job for reasons that could be attributed to experience, education, and stability. The higher impact of job security might be further captured when one analyzes the 2012 Census data on poverty which shows a higher proportion of young people living in poverty than older people. The poverty rate of those 65 and older was $9.1 \%$ in 2012 while the poverty rate for those 18 and younger was 13.7\% (DeNavas-Walt et al., 2012). Furthermore, the Census data shows that more young people are without health care than older people.

Typically, people with good stable jobs have access to healthcare benefits and the fact that young people are disproportionately without healthcare indicates that they do not have well-paying stable jobs; at least not in comparison to older generations. People between the ages 18 - 30 are usually in the process of figuring out what they want to do with their life; what career path they want to take. People between this age group are often committed to school and are unable to commit to a full time work schedule. Naturally, in a situation of strenuous circumstances, part time positions which are often occupied by those between ages 18 - 30, are the first to be cut. The 2012 Census indicates that in 2012 only 2.9\% of full time employees lived under poverty while $7.3 \%$ of part time employees lived in poverty (DeNavas-Walt et al., 2012). The New York Times published a spectacular article which gave a litany of some of the challenges young college age adults face in the modern American context. According to the article, college costs have increased $60 \%$ in the past few decades. As a result, more students have to work while attending college than ever before (Deparle, 2012). The anxiety that one might feel about these facts is more than probative in explaining the high marks given by those between ages 18 - 30 on the question of job security.

In that regard, the middle age cohorts do not view job security as a big issue because they presumable have the education, and the experience to be considered more valuable assets to the job. Many middle age cohorts are the bosses of the young cohorts and therefore have to worry less about losing their jobs. Those in their mid-age are often more stable than the younger generation and can keep a job longer than the younger cohorts who might have to change jobs due to schooling and other life situations. The 2012 US Census released that the highest earning brackets consists of those between ages 35 - 54. This is the age when most Americans earn the most in their careers (DeNavas-Walt et al., 2012; Pew Research Center, 2013; Jäntti, 2006). Therefore, it is less likely that this group would

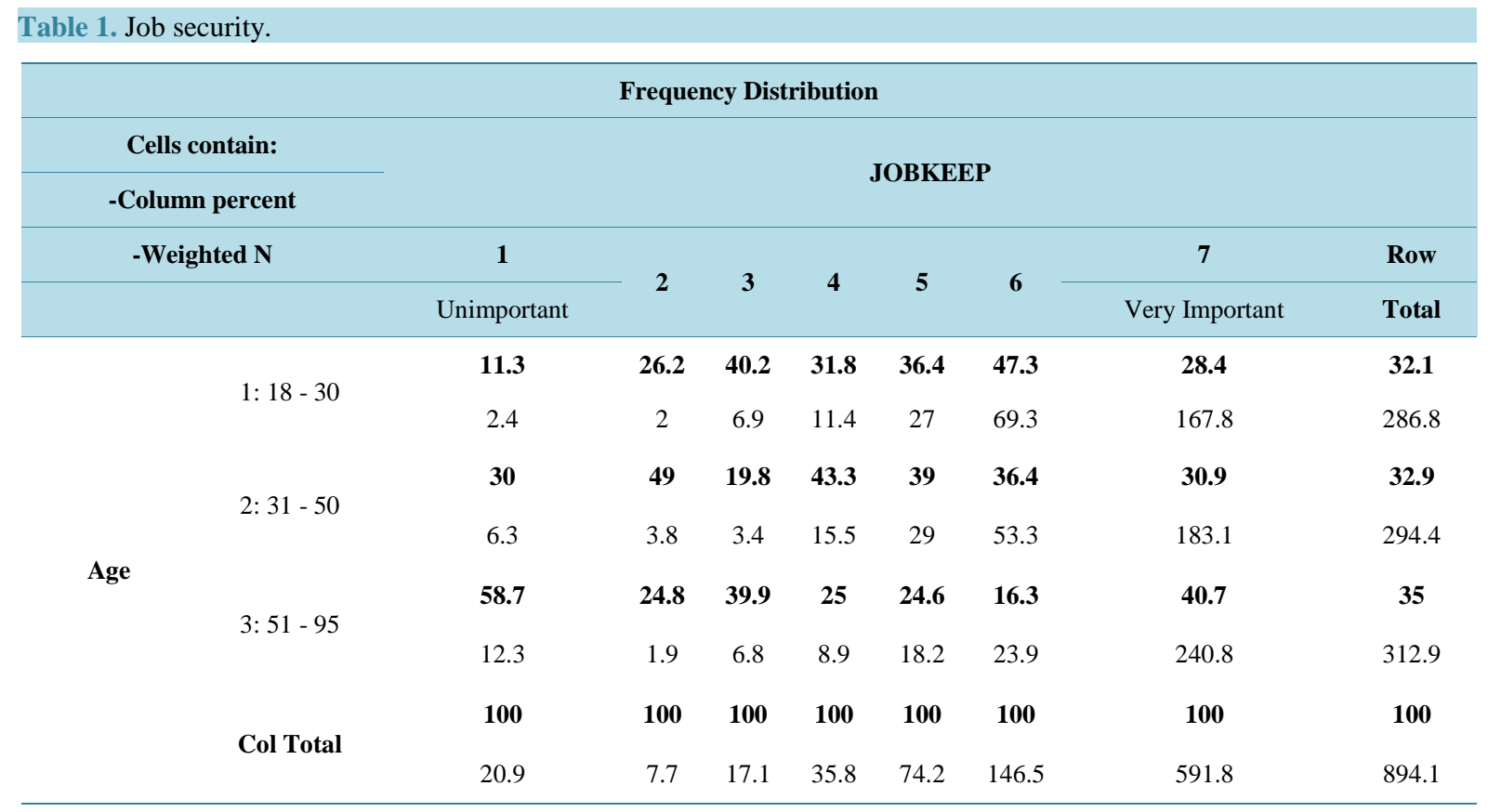


be very concerned about job security. It might also be noted that by the ages 31 - 50 more Americans are married and therefore have shared income. There have been much research in recent times that directly correlate one's economic status with marriage. Married couples on average have higher income than non-married individuals (Jäntti, 2006; Pew Charitable Trust, 2012; DeLeire \& Lopoo, 2013).

The higher income which the middle aged cohorts enjoy provides them with more freedom and power in the job market. Although on average this population enjoys the best aspects of the job market, the fact still remains that they are still participants in the market and are still at some risk of losing their jobs. And so it makes since that this group would be less concerned about job security than the younger generation but more concerned than the old generation. The older generation as before mentioned is least concerned of all the generations about job security. The younger half of this cohort, those between the ages 51 - 70, in theory have more job experience and education. This group is also more stable than the younger generations. The older half of this generation might account for the lower number of those unconcerned about job security because most of them are retired. That is, they no longer have to worry about job security because they don't work. Many of the members of this generation enjoy Medicaid and social security benefits. They are not faced with the same sorts of challenges that the younger generation faces with school, and lack of healthcare and all the other assortment of issues that group faces.

In Table 2, when asked if traditional class divisions still exist, more people between ages 18 - 30 (39\%) thought that they do not still exist. A larger number of those between ages 31 - 50 thought that traditional class divisions do still exist with $43 \%$ strongly agreeing. Those between ages 51 - 95 had responses that were pretty close with a 5.7 margin between the highest and lowest response rates. However, marginal, the oldest generation had more respondents who strongly agree (31.3\%) and somewhat agreed (32\%) than those who somewhat disagreed (28.2\%) and those who strongly disagreed (25.6\%) on the question. On the issue of class division, there appears to be a clear generational divide between the old and the young generation with the older generations agreeing that traditional class division still exists. The majority of the younger generation do not see traditional class division as something that still exist. Max Weber provides a basis upon which one may properly apply the concept of class. According to Weber, class is determined by market situation which is,

"Represented exclusively by economic interest in the possession of goods and opportunities for income" (Weber, 2013).

Therefore, the very act of recognizing class, which is basically one's economic positioning in relation to others, is a privilege and an act of power. Following this school of thought, it can be anticipated that those with more economic capital will be more inclined to identify class division as it is the primary identifier of one's socio-political standing in society, and one of the most obvious indicators of one's power.

\section{Table 2. Traditional class division.}

\begin{tabular}{|c|c|c|c|c|c|}
\hline \multicolumn{6}{|c|}{ Frequency Distribution } \\
\hline 0 & \multicolumn{5}{|c|}{ USCLASS1 } \\
\hline \multicolumn{6}{|l|}{-Column percent } \\
\hline \multirow[t]{2}{*}{-Weighted N } & 1 & 2 & 3 & 4 & Row \\
\hline & $\begin{array}{l}\text { Strongly } \\
\text { Agree }\end{array}$ & $\begin{array}{l}\text { Somewhat } \\
\text { Agree }\end{array}$ & Somewhat Disagree & Strongly Disagree & Total \\
\hline \multirow{2}{*}{$1: 18-30$} & 25.4 & 30.5 & 34.1 & 39 & 31.1 \\
\hline & 58.2 & 224.2 & 119.1 & 33.1 & 434.6 \\
\hline \multirow{2}{*}{$2: 31-50$} & 43.3 & 37.4 & 37.7 & 35.4 & 38.3 \\
\hline & 99.4 & 274.8 & 131.5 & 30 & 535.7 \\
\hline \multirow{2}{*}{ 3: $51-95$} & 31.3 & 32 & 28.2 & 25.6 & 30.6 \\
\hline & 71.8 & 235.2 & 98.4 & 21.7 & 427.2 \\
\hline \multirow{2}{*}{ Col Total } & 100 & 100 & 100 & 100 & 100 \\
\hline & 229.4 & 734.2 & 349 & 84.9 & 1397.50 \\
\hline
\end{tabular}


If one were to apply Weber's theory of class to the results of the data, one would argue that because the younger generation generally doesn’t have much economic power in regard to possessing property, and other goods and income, they are less inclined to identify with traditional class divisions. Digressing from Weber's theory, consider this; The Millennial generation is the most diverse generation in American history. This generation has grown up in a time where the middle class has vastly expanded to include more historically marginalized groups (DeNavas-Walt et al., 2012; Pew Charitable Trust, 2012; Deparle, 2012). They are more likely to have friends across class lines, blurring the perception of any real class divide. In the current socio-political landscape, it is often unclear what actually divides the various classes. The concept of the American middle class is a fluid ideal that changes from place to place, person to person. Thus, in the case of the Millennial generation, it might be a question of identifying the various classes. Without this understanding, it would be difficult for the Millennial generation to form an opinion on whether so called traditional class divisions still exists.

Of all the generations surveyed the middle aged had the strongest opinions on the question of class division. More participants from this group strongly agreed that class division still exists in America. Weber would argue that this is because they are the ones with all the capital and therefore, all the power. It is necessary to their social status to be in tuned with their own class and know where they stand in relation to others. To better understand this generation's strong response it might prove valuable to consider the history of this cohort. This group consists of what most experts consider the Gen Xers. This generation came after the movers and shakers of the 1960s who seemed to have achieved many of the great things which we enjoy today, including: passing the most comprehensive Civil Rights Act, establishing Medicare and Medicaid and ending the Vietnam War. According to Howe and Strauss, Gen Xers came into the world with low expectations of what they could achieve both from the older generations and from themselves. This fact was reflected in their low test performances and high crime rates (Howe \& Strauss, 2000). Being young adults during the days of boomer activism in the 60s this generation has witnessed some of the most massive reforms brought about by the generation before them. Their belief that traditional class division still exists might be a reflection of their low performance in the area of socio-economic change compared to the Boomer generation.

The older generation also seemed to agree that traditional class division still exists in American culture. This age group ranging from 51 - 95 consists of two generations combined in one; the Baby Boom generation and the Silent Generation. The numbers for this last age group most likely doesn't tell the full story of the respondents. There might be different reasons for the responses of each of the two generations that are grouped in this category. The Baby Boomers came into a very segregated world both in terms of race and class. They had the determination to change the conventional order of their time for a new more just society (Matusow, 2009). In many ways, they achieved these ends but their victories were met with many defeats as well. Although Boomers sparked cultural and social change, they eventually became consumed by the conservative American machine and could not impact any real political-economic change (Matusow, 2009). The Boomers who came of age with benign sentiments towards the government would experience the failure of two presidencies-LBJ's Great Society and Richard Nixon. After the passage of the two civil rights legislations, the Boomers waged a cultural war that drained their energies and could not do much in the realm of class struggle (Matusow, 2009). Therefore, the high rate of Boomer respondents that agreed that traditional class division still exists are likely responding to the fact that in their effort to bring about overwhelming change, they missed their mark on the class issue.

One can suspect that the Silent Generation was more in the middle on the question of traditional class division. On one hand, they came of age during a very segregated time in American history like the Boomers; but on the other hand, they have witnessed the expansion of the middle class and the increase of working wage (Harris et al., 2011; DeNavas-Walt et al., 2012; Deparle, 2012; Isaacs, 2013). Unlike the younger Millennials, the Silent generation did not grow up in a very diverse America. For the most part, people associated with others who were of the same socio-economic-class status. In this regard, it is easy to distinguish a division along class lines. The overall response of those between 51 - 95 are most likely over represented of the Baby Boom generation considering the fact that they are substantially more in number than the Silent generation.

In Table 3, when asked if one is able to live well in America, more people between ages 18 - 30 strongly disagreed (39.9\%), compared to 30.6\% who strongly agreed. For those between ages 31 - 50, respondents more strongly agreed that one is able to live well in America (37.1\%) than strongly disagreed (33.5\%). More people between ages 51 - 95 strongly agreed (32.3\%) than strongly disagreed (30.8\%) to the question. According to the Brookings Institute (2006), more women are in the workforce now than previous generations, and average earning has increased for women, while average income has remained flat for men. In general, income has risen per- 
Table 3. The American dream.

\begin{tabular}{|c|c|c|c|c|c|}
\hline \multicolumn{6}{|c|}{ Frequency Distribution } \\
\hline Cells contain: & \multirow{2}{*}{\multicolumn{5}{|c|}{ EQUAL6 }} \\
\hline -Column percent & & & & & \\
\hline \multirow[t]{2}{*}{-Weighted N } & 1 & 2 & 3 & 4 & Row \\
\hline & $\begin{array}{c}\text { Strongly } \\
\text { Agree }\end{array}$ & Somewhat Agree & $\begin{array}{c}\text { Somewhat } \\
\text { Disagree }\end{array}$ & Strongly Disagree & Total \\
\hline \multirow{2}{*}{ 1: $18-30$} & 30.6 & 32.2 & 24 & 39.9 & 31 \\
\hline & 204.2 & 191.2 & 30.3 & 18.2 & 443.9 \\
\hline \multirow{2}{*}{$2: 31-50$} & 37.1 & 39 & 41.6 & 33.5 & 38.2 \\
\hline & 247.7 & 231.5 & 52.5 & 15.2 & 546.9 \\
\hline \multirow{2}{*}{ 3: 51 - 95} & 32.3 & 28.8 & 34.5 & 26.6 & 30.8 \\
\hline & 215.5 & 170.6 & 43.5 & 12.1 & 441.7 \\
\hline \multirow{2}{*}{ Col Total } & 100 & 100 & 100 & 100 & 100 \\
\hline & 667.4 & 593.4 & 126.3 & 45.5 & 1432.50 \\
\hline
\end{tabular}

generation. That is, the Baby Boom generation makes, had, or has higher average earnings than the Silent generation - and Gen Xers on average have higher earnings than Boomers; and that Millennials are projected to earn more than any of the previous generations (Isaacs, 2013). Given these facts, Millennials largely believe that many inequalities still exist. A recent Pew research shows that Millennials believe that women are still paid much less than men for the same work and do not believe that enough is being done to address gender inequality (Pew Research Center, 2013). So even though the Millennials are coming up in an age where women are about half of the work force and are,

"Better educated than their mothers and grandmothers had been—or than their young male counterparts are now" (Pew, 2013).

It is no surprise that the younger generation is largely unsatisfied with one's ability to live well in America.

Research has shown that the millennial generation does not have the same optimism regarding American exceptionalism as older generations (Jäntti, 2006). A 2006 research conducted by the Institute for the Study of Labor compared the United States' performance on income mobility to Great Britain and four Nordic countries (Denmark, Norway, Finland, and Sweden). The research found that the Nordic countries have the highest intergenerational income mobility and that the US ranks last in income mobility. The research also found less upward mobilization in the bottom $5^{\text {th }}$ quartile and less downward mobilization in the top $5^{\text {th }}$ quartile (Jäntti, 2006). Other researches have found an increase in poverty concentration and an ostentatious increase in wealth gap (Harris et al., 2011; DeNavas-Walt et al., 2012; Kneebone et al., 2011; Deparle, 2012). The Millennials see, hear, or read about these things through the internet and other sources and can't help but think that their world is not as good as it could be. They appreciate the American values of freedom and liberty but also acknowledge that there are other countries who have made equal or greater strides to these ends.

Much of the Millennials' experience in America has been characterized by unfavorable wars, questionable political maneuvering such as the Patriot Act and the worst economic condition since the Great Depression. In short, the Millennials have not had a lot to be optimistic about. Perhaps most importantly, the Millennials recognize the progress which previous generations have made but are not content with the seemingly stagnant state of the country today. In this way, most Millennials most likely responded to the question through a social justice perspective. They believe that America has not fully delivered on its' promise of liberty and justice for all, and recognize that there are still large populations who do not have full equality in America (Harris et al., 2011; DeNavas-Walt et al., 2012; Pew Charitable Trust, 2012; Pew Research Center, 2013; Deparle, 2012; Kneebone et al., 2011). It therefore does not come as a surprise that they are more pessimistic about one's ability to live well in America.

In contrast to the Millennials, each of the older generations have had ample time to witness and experience 
worse moments in American history. For the Gen Xers, events like the LA riots, the crack epidemic, and the Iranian Hostage crisis play vividly in their conscience. For Boomers events like the death of JFK, RFK, and MLK as well as the Vietnam War and Water-gate might over shadow any current issue. For the non-racist majority of the older generation, America is better now than it was when they were growing up. In addition, those who control society are the older generation. They make the laws and enforce them. They are the CEOs and presidents at the jobs which employ the younger generation so if they have any complaint about America, they can shape it to their liking. Given the fact that most, if not, all of the political socio-economic capital is in the possession of the older generations, it makes sense that they largely agree that one can live well in America. This is their experience and their truth.

\section{Conclusion}

From the data analyzed one can conclude that when it comes to issues related to socio-economic class, the older generations (Gen Xers, Boomers/Silent) are more closely aligned with each other than with the younger generation (Millennial). This supports Howe and Strauss's argument. We will revisit this point after a brief analysis of how the data supports MacManus' hypothesis. The results validate MacManus' argument that people respond positively to issues that they perceive to directly impact their cohorts. This is evidenced from the responses of each generation on the question of job security. The data showed that the younger generation is more concerned about job security because they are potentially at greater risk of being fired for the reasons provided above. On the other hand, each of the older generations did not consider job security to be of grave concern because they were at lower risks of losing their jobs compared to the younger generation. The data from this research did not yield any conclusive evidence to prove MacManus's thesis that age, not generation, influences political action. The data confirms Howe and Strauss's main argument that the Millennials are basically in a tug of war with all the other generations. In each of the categories: job security, class division, and the American dream, the older generation responded in concert while the younger generation stood alone. Although it is not clear how much influence age as a separate agent affects people's stances on economic and class issues, evidence from this data point to a clear generational divide between the young Millennial generation and older generations namely: Gen Xers, Baby Boomers, and the Silent Generation. This data yields conclusive evidence that generation as a variable in researching socio-political attitudes is worth studying.

With that being said, there seemed to be two additional forces influencing both the result and interpretation of the data. Both of these influential factors are found in McManus' life cycle theory. The first fact is on the issue of age. One cannot communicate the findings of the data without consideration of age. Recall that the essential fact of lifecycle theory is that age positively correlates to political interest and engagement. No conclusive findings were yielded on the topic of political engagement but there is something to be said about age. In this research, it was impossible to segregate the age variable from that of generation. And so, in the attempt to make a purely generational argument, age had to be considered because the tables distinguished generations by age. The other variable that came to play in the interpretation of each table was the other aspect of the life cycle theory, interest. In one way or another, the findings in each of the datasets were explained through a self-interest paradigm. For example, on the question of job security, each of the explanations provided were essentially based upon what was in the best interest of cohort. While it a pure observation of the data may suggest that Howe and Strauss' generation theory stands alone as the strongest theory to explain the research, when one begins to interpret the data, McManus' life cycle theory complements the narrative. This paper therefore resolves that the three variables; age, interest, and generation are inextricably linked. The data further yields that on economic issues, the older generations; Gen Xers, Boomers, and Silents are more optimistic than the Millennials. Each of the generations appear to be more passionate about issues that they perceive to directly and perhaps immediately affect their cohorts. Each of the generations including the Millennials appear to have a strong sense of which issue affect them the most. The issues which are perceived as having a negative impact presented higher marks perhaps as an expression of passion from that particular cohort.

It would be to the benefit of this study and others in the field for future researchers to conduct univariate research on the variables, age, generation (clearly defined), and interest. Such a study might shine some light upon the question if the three variables can in fact be separated so as to conduct individual studies upon them. The paper also invites future research involving other issue choices in order to test whether or not the result will be identical to the findings of this paper in regard to the relationships of generation, age, and interest. Such research will add to the current scholarship, and further enrich the understanding of the role in which generation, age, and 
interest plays in political and civil action.

\section{Acknowledgements}

Professor David Schultz, the Open Journal of Political Science, and Esha Seth.

\section{References}

Carpini, M. X. D. (1989). Age and History: Generations and Sociopolitical Change. In R. S. Sigel (Ed.), Political Learning in Adulthood: A Sourcebook of Theory and Research (pp. 1-18). Chicago: University of Chicago Press.

DeLeire, T., \& Lopoo, L. M. (2010). Family Structure and the Economic Mobility of Children.

DeNavas-Walt, C., Proctor, B. D., Smith, J. C., \& US Census Bureau (2012). Income, Poverty, and Health Insurance Coverage in the United States: 2012. Washington DC: United States Census Bureau.

Deparle, J. (2012). For Poor, Leap to College Often Ends in a Hard Fall. The New York Times.

Harris, E., Sammartino, F., \& United States (2011). Trends in the Distribution of Household Income between 1979 and 2007. Washington DC: Congress of the United States, Congressional Budget Office.

Howe, N., \& Strauss, W. (2000). Millennials Rising: The Next Great Generation. In R. J. Matson (Ed.), Cartoons. New York: Vintage Books.

Isaacs, J. B., \& Brookings Institution, Washington DC. Economic Mobility of Families across Generations. Economic Mobility Project.

Jäntti, M. (2006). American Exceptionalism in a New Light: A Comparison of Intergenerational Earnings Mobility in the Nordic Countries, the United Kingdom and the United States. Bonn: IZA.

Kneebone, E., Nadeau, C., \& Berube, A., Brookings Institution (2011). The Re-Emergence of Concentrated Poverty: Metropolitan Trends in the 2000s. Washington DC: Metropolitan Policy Program at Brookings.

MacManus, S. A. (1995). Young v. Old: Generational Combat in the 21st Century. Boulder, Colo: Westview Press.

Mannheim, K. (1952). The Sociological Problems of Generations. In P. Kecskemeti (Ed.), Essays on the Sociology of Knowledge (pp. 163-195). New York: Oxford University Press.

Matusow, A. J. (2009). The Unraveling of America: History of Liberalism in the 1960s. Athens, Georgia: The University of Georgia Press.

Pew Charitable Trust (2012). Pursuing the American Dream: Economic Mobility across Generations. Economic Mobility Project. http://www.publicradio.org/marketplace-archive/pdf/pew american dream.pdf

Pew Research Center (2013). On Pay Gap, Millennial Women Near Parity_For Now: Despite Gains, Many See Roadbloacks Ahead. http://www.pewsocialtrends.org/files/2013/12/gender-and-work_final.pdf

Walsh, K. C., Jennings, M. K., \& Stoker, L. (2001). The Effects of Social Class Identification on Participatory Orientations towards Government. British Journal of Political Science, 34, 469-495.

Weber, M. (2013). Class, Status, and Party. http://www.ac.wwu.edu/ jimi/363/webercsp.pdf 